\title{
3q Abnormality
}

National Cancer Institute

\section{Source}

National Cancer Institute. 39 Abnormality. NCI Thesaurus. Code C158849.

An irregularity in the structure of the long arm of chromosome 3. 